\title{
Drug Prohibition: A Legal and Economic Analysis*
}

Walter Block

ABSTRACT. This paper argues the case for the legalization of addictive drugs such as marijuana, cocaine, and heroin. It maintains that there are no "market failures" which could justify a banning of these substances, and that, as in the earlier historical case of prohibition of alcohol, our present drug policy has increased crime, decreased respect for legitimate law, and created great social upheaval.

\section{Introduction}

This paper shall argue the case for the legalization' of addictive drugs such as marijuana, cocaine, and heroin. In Section II the claim is defended that there are no "market failures" which could justify a banning of these substances. Section III makes this point with regard to the libertarian theory of law. In Section IV several objections to this thesis are explored and rejected, and Section V concludes with an analysis of the benefits of legalization.

A member of the faculty of the Economics Department of the College of the Holy Cross, Worcester, MA, Dr. Walter Block is Adjunct Scholar at the Fraser, Cato, and Mises Institutes. His professional affiliations include the American Economic Association, and Western Economic Association, the British Columbia Association of Professional Economists, the Canadian Economic Association, the Canadian Association for Business Economics and the American Law and Economics Association. He has previously taught at Stony Brook (S.U.N.Y.), Baruch (C.U.N.Y.) and Rutgers Universities, and has worked in various research capacities for the National Bureau of Economic Research, the Tax Foundation, The Financial Post, Western Report, and Business Weck. Dr. Block has published numerous popular and scholarly articles on economics and writes a syndicated column for Sterling newspapers. An economic commentator on national television and radio, he lectures widely on public policy issues to university students, service, professional and religious organizations.

\section{Economics}

There is nothing in the tenets of value free economics ${ }^{2}$ that would preclude the legalization of drugs. On the contrary, the presumption from this quarter is that a free market in marijuana, cocaine. heroin, and other such substances will enhance economic welfare.

This somewhat startling conclusion emanates from the axiomatic nature of the proposition that there are always gains from trade. Whenever any two persons engage in commercial activity - whether it be barter, or for employment, or the purchase or sale of consumer goods or intermediate products both must gain in the ex ante sense. That is, neither party would agree to take part in the endeavor did he not expect to be made better off as a result of it. If I purchase a newspaper for $\$ 0.50$, I do so only because I predict that I will enjoy its perusal more than any other usage of this money; conversely, the vendor prefers the coins I give him more than the paper and ink he must give over to my possession.

The claim being made here, strictly speaking, is not that a free market in drugs (or anything else for that matter) will enhance economic welfare ex post, but rather only in the ex ante sense. When one views a trade $e x$ ante, he does so from a time perspective beforc it actually takes place; he anticipates that he will benefit from it. And that is the reason he agrees to take part in it in the first place. Economic welfare from the ex post sense is from the perspective of after the trade occurs. For him to have gained in this regard, the participant must continue to regard himself as better off because of it.

There is indeed a strong presumption that trade benefits both partners in both senses. However it must be acknowledged that every once in a while a consumer regrets making a purchase; perhaps the 
price has fallen in the interim between the point of sale and the ex post evaluation. Or a vendor later regrets selling an item, because he now thinks it was of higher quality than he estimated when he agreed to the sale.

If this insight applies to ordinary trades, it holds no less in the case under consideration. Were I to sell to you an ounce of cocaine for $\$ 100$, it must be true that at the point of sale, I value the money more than the opiate, and that you rank the two items in the inverse order. Since trade is a positive sum game, we both gain.

It cannot be denied that third parties to this arrangement will often feel themselves aggrieved. There are legions of decent citizens who are sometimes affronted when consenting adults engage in voluntary capitalist acts. Temperance leagues object to alcohol sales, health nuts are enraged at cigarette advertising, and, for all we know, there may be people who are in principle opposed to the publication, sale, and reading of newspapers. None of this, however, vitiates our original economic insight. The market, the concatenation of all voluntary trades, still enhances the welfare of all participants (Rothbard, 1977). These objectors may be participants in other market activities, but as third parties, their misgivings are simply not included in our welfare calculations.

There are several good reasons for disregarding the welfare of third parties. ${ }^{3}$ First, a praxcological reason. According to the old saw, "talk is cheap, action is what counts". Any third party is free, of course, to verbally oppose any given trade. For example, feminists and conservatives oppose the sale of pornography; teetotalers argue against the purchase of intoxicants; Jews and Muslims decry markets for pork. The point is, however, that these opponents are limited in their opposition, to talk; there is no action which necessarily reveals their truc assessment. At least they cannot demonstrate their preference in the manner in which the trade of the two parties to the transaction indicates a positive evaluation of the item received compared to that which is given up. ${ }^{+}$

Second, a pragmatic one. In theory, no trade can escape this criticism. There can always be found at least one person who will object to each and every trade ever made. Died in the wool Marxists fit this bill; they see commercial activity as necessarily exploitative. Additionally, those who favor self sufficiency and carry this to its logical conclusion, are in principle committed to disputing the validity of all exchanges. This applies as well to those who think that we ought to be giving each other presents instead of buying and selling to one another. However, it is rather an unfair hurdle to expect a market defense of legalized drugs to satisfy a philosophy which can even call into question the pedestrian exchange of $\$ 0.50$ for a newspaper.

Third, a reason which clarifies the claim being made in the present paper. We are not affirming that the market makes everyone on earth better off; on the contrary, it merely enriches those who take part in it. Third parties, by definition, do not, in the specific and limited contexts in which they are third parries, take part in market transactions. Therefore, no benefit accrues to them on those occasions. Our interest is not in maximizing overall welfare; merely that of market participants. Anyone of course, is free to enter the market, and offer goods or services in trade. On such occasions, their economic welfare can or will be enhanced. But, strictly speaking, the welfare of third parties qua third parties cannot be counted, since we do not contend that their welfare will be improved.

However, we need not necessarily confine ourselves to "speaking strictly," within the paradigms of welfare economics. We can also speculate, albeit as unscientifically as do all other commentators, on the third party effects of drug legalization. While it is obvious that there will be some third parties who feel themselves aggrieved (there could hardly be a prohibition on the books were this not the case), it is no less true that many others will benefit from the reduction in crime, drive by shootings, etc.

Another, related, point must be made at this juncture. When we claim that the welfare of third parties qua third parties cannot be counted, and therefore must be distegarded, we most certainly do not have in mind a transaction between $\mathrm{A}$ and $\mathrm{B}$ for the murder of C. Even though A and B undoubtedly gain in the ex ante sense from such an agreement, $\mathrm{C}$ is not at all a "third" party. On the contrary, he is a second party, to whichever of them, A or B, is assigned the task of murdering him. As such, there is no agreement between $\mathrm{C}$ and $\mathrm{A}$ (or B), ${ }^{5}$ so there is no presumption of mutual gain. In other words, we only "disregard" the effects on third parties such as C 
when the consequences which occur are permissable by libertarian standards. Rights violations (e.g., murder), as opposed to conceivable (albeit unprovable) "harms" such as C disliking A selling drugs to B, do not qualify.

\section{Law}

There are basically two kinds of law in this context: normative and positive. The latter is confined to actual legislative enactments, and judicial interpretations. Since the bottom line on this literature is that certain drugs are now illegal in the U.S., a discussion of this aspect of law would be uninteresting and unedifying.

Instead, we concentrate on the former. In particular we focus on the libertarian legal code, insofar as this is one philosophy consistent with full legalization, the position we wish to defend. In this John Locke based perspective, man is the owner of his own body, since he, in effect, "homesteaded" it, and likewise of all parts of the natural world with which he has mixed his labor. Given that he legitimately owns these properties, he can do with them whatever he wishes, provided that he respects the equal human and property rights of all other people.? Thus, a man can use his domicile for target practice, provided he keeps the bullets confined to his own premises; if ever they stray onto the property or bodies of other persons, his actions are no longer consonant with the libertarian legal code.

Under such a regime, a man can properly attain new property by any legitimate non coercive means (Nozick, 1974): inheritance, gambling, work, and, particularly relevant to our concerns, trade. That is to say, if A homesteaded some land, and grew marijuana plants on it, and B earned some money in any other legitimate occupation, then it is entirely legitimate for $\mathrm{B}$ to purchase this commodity from $\mathrm{A}$. Even more important, it is then proper (e.g., it should be legal for B) to use this item in any manner, shape or form which does not violate the right of others to use their persons and property in a manner of their own choosing. That is to say, $\mathrm{B}$ is allowed under the libertarian legal code to ingest or smoke the marijuana, but not to use it as a projectile to throw at his neighbor.

The implication of an interference with this right of marijuana use is (partial) slavery. The problem with this "curious" institution is that the control of each of us over our own bodies is abrogated. Are we being hysterical in categorizing present drug law as a form of slavery? It is all a matter of degrec; there is never total abrogation. For example, in the epoch of U.S. slavery before the close of the Civil War, slaves were denied to right to come and go as they wished, and to work for any willing employer. Rather, they were typically confined to one particular plantation, and owned by other people. However, they did have a certain limited control over their bodies: they were allowed to sleep; they were allowed to eat; they were allowed to engage in their other bodily functions.

It is no different with the prohibition of dope, except in the matter of degree. In both cases our control over our bodies is restricted. In slavery, this occurs almost but not quite totally; in the present case, the limitations concern merely the right of ingestion of illegal substances. But insofar as interference with our control over ourselves is proscribed, we are to that extent enslaved. ${ }^{8}$

\section{Objections}

1. Addictive materials are physically harmful to the person who uses them. They should therefore be banned

Given the purely economic perspective, we are entitled to deduce from the fact that a man buys narcotics the conclusion that he values them more than their cost. And that is all. It cannot be shown, as attempted by Stigler and Becker (1977) that there are "beneficial" and "harmful" addictions, according to whether or not they enhance, or detract from, the earning of income in the future. Why is it necessarily "beneficial" ("harmful") to engage in activity which promotes an upward (downward) sloping life time earnings profile? Whether the individual chooses an example put forth by these authors in the former category (e.g., classical music) or in the latter (alcohol), the value-frec economist cannot categorize them as beneficial or harmful. All he can conclude is that, in the view of the economic actor, at the time the decision was made, the choice of consumption, whether alcohol or Amadeus, was made in order to enhance his welfare."

If pure economic theory cannot support this 
distinction between "good" and "bad" addictions, even less so can it be used in behalf of the case for interdiction. For even if it could somehow be established that heroin is a harmful addictive substance, in the absence of a value judgement it by no means follows that it should be outlawed. ${ }^{16}$

The paternalistic argument (bad addictive materials should be legally prohibited) undoubtedly rings true from a health point of view, in that if there were any such, ending their use would be a medical accomplishment. But this is irrelevant to public policy analysis, at least from the libertarian legal perspective. There are many other things that are deleterious; for example, chocolate, ice cream, hang gliding, ice skating, boxing, fatty foods, automobile racing, fried chicken. Were we to accept this argument in the present case, logic would require that we forbid all such items, and activities. But this would surely be an infringement on self-ownership rights.

Let us now concede for the sake of argument that heroin is harmful. Even so, injury is a relative, not an absolute concept. Harmful, but compared to what? Alcohol? Tobacco? Many more people - even proportional to actual use - die of the latter two than of the former. If foreclosure is indicated, it is thus by no means clear as to which item it should be applied. Further, legal suppression does not improve, but rather exacerbates the health problem. This is because of the potency effect of prohibition: the mere existence of prohibition, and the more sevcrely it is administered, the stronger will be the potency of the ensuing drugs. A smuggler would rather risk transporting a suitcase full of cocaine than marijuana, because of its greater value. The same phenomenon occurred with alcohol in the early part of the 20th century: beer manufacture declined, while that for hard liquor increased. This, too, is the cxplanation for the most recent generation of chemical substitutes: crack, ice, PCP, ctc.

If anything is harmful for human consumption, rat poison and carbon monoxide fit the bill. And yet our society has not so far legally excluded these items from commerce. There are some people who even go so far as advocate entrenching into law the right of suicide. These individuals, as in the case of the pro-choicers, are logically obligated to support repeal. For at worst addictive drugs are a (slow) form of suicide. If we do not advocate disallowing these other death aids, nor even doing away with oneself, how then can we logically proscribe substances such as heroin?"1

\section{Addictive drugs are financially harmful to the persons other than the one who uses them. They should therefore be forbidden}

This is true, but only under a regime of socialized medicine. There, we are indeed each "our brother's keepers." If you overeat, and contract heart disease, I, along with everyone else, am forced to pay for it. If I smoke cigarettes and fall victim to cancer, you, and all other citizens, must foot the bill. We, therefore, each have a clear and focussed interest in the health habits of everyone else. The individual is a "clear and present" financial danger to the group. In such a situation, there certainly is a case for the injunction of addictive material: the rest of us can save money if we can reduce the incidence of use.

But why accept this context as a fact of nature? Coercive medical insurance schemes have many shortcomings, not the least of which is the problem of moral hazard, which encourages all parties to overuse scarce health services since they are priced at subsidized costs. ${ }^{12}$ Given a free market in medicine, this reason for restraint of drug markets all but vanishes.

Further, alcohol and tobacco, as we have seen, are far more harmful than addictive drugs. To the extent that this objection has any merit, we should first enact legislation against the former, and only then prohibit the latter.

In contrast, this Hobbesian war of each of us against the other does not occur under a market regime. There, it is to the financial interest of private medical insurance companies to set prices which reflect the best estimated risk of future health care needs. For example, if a person smokes, or drinks or engages in any number of dangerous activities such as eating chocolate, ice cream, or fatty foods, hang gliding, ice skating, boxing, etc., their insurance premiums will tend to take this into account. In equilibrium, the risk of these dangers will be fully incorporated, no more, no less: the charges cannot be any higher than the levels predicted by these activities due to competition from other firms; they will not be any lower, since bankruptcy will eliminate such practices. 
But what of the objection that insurance companies do not currently charge lower rates to nonalcoholics? There are several replies to this. First of all, we do not at present have an insurance industry based fully on free market principles. There are simply too many barriers to entry - regulations, prohibitions against foreign carriers in the local market, domestic entry restrictions - for that. Were there no barriers to entry, and if it were profitable for companies to discriminate against alcoholics, the presumption is that this is precisely what would occur. Secondly, ill health is now dealt with by the courts as a handicap, and handicap is now in the process of becoming a status against which it is illegal to discriminate. If alcohol is interpreted as more of a protected handicap than tobacco, due, perhaps, to secondary effects, ${ }^{13}$ this may explain why insurance companies are loath to apply their cigarette policy to liquor. If there were absolutely no law against discrimination, insurance companies would likely be able to ensure that one person need not subsidize another's indulging in chocolate or fatty food consumption: they could measure the blood pressure, height and weight, etc. of their clicnts. They could subject them to other medical tests: heart beat rate after 5 minutes on a treadmill. They could ask them to sign a statement attesting to the fact that they do not engage in activities such as skiing or hang gliding: violations would annul insurance coverage. Needless to say, any such market responses (which would tend to make our lives safer) would be severely dealt with by the courts (Epstein, 1992).

\section{Addictive drugs promote crime, and should therefore be banished}

This is perhaps the weakest objection of all so far, in that it is the suppression of narcotics that leads to criminal behavior, not these substances themselves.

If left to the market, the prices of heroin, cocaine, marijuana and all the rest would be exceedingly modest. After all, they are based for the most part on very hardy plants, which cost little to harvest and process. The reason they are so expensive at present is because of their legal status: it is highly risky to bring them to market. The high prices they can fetch, however, create vast profits. These attract people whose adherence to the niceties of the law are less than thorough.

Crime comes about in three ways based on this sccnario. First, the farmers, refiners, transporters, street vendors, etc., involved in the practice are per se considered criminals, since they break the law. But this is not "real crime," since there are no victims of these commercial interactions; all the way from planting the seed to final consumption there are only willing participants involved.

Second, because of the exorbitant costs of the drugs, addicts must resort to crime (burglaries, auto theft, assault and battery, etc.) in order to obtain the funds necessary to feed their habits. Here, there is at last real crime, since the victims by no stretch of the imagination can be considered to have given their permission to the perpetrators.

Third, are those who pay the ultimate penalty as a result of gun battles in the streets between different gangs contending for turf. These "mushrooms" are also entirely innocent, and lose their lives not because of drugs in and of themselves, but rather due to the law. This is because it is not possible for an aggrieved drug gang member to utilize the courts and police; rather, he must "take the law into his own hands." A similar situation occurred during the epoch of alcohol prohibitionism, and the same people then as now are ultimately responsible for the deaths of the innocents: the legislators who enacted the law, and the police and jurists who administer it.

Despite the foregoing, there are claims to the effect that narcotic usage creates crime in a very different way: by turning the addict into a crazed, enraged lunatic, uncontrollable in his lust to lay waste to the countryside, and all who reside in it. This "Godzilla" effect is entirely erroneous when applicd to the traditional opiates. ${ }^{1+}$ There are three bits of evidence which can be adduced in behalf of this claim. One is the British experience with legalization, where doctors in hospitals would not start newcomers out on this path, but would administer the drug to confirmed addicts. The finding from this source (Judson, 1974) is that the recipients of this medication were able to lead normal lives without any extraordinary involvement in criminal activity. Second are the opium dens of Chinese origin. The denizens of these establishments, too, were not given over to violence; if anything, the very opposite was the case. This substance induced lethargy, if any- 
thing. And third is the example of the one segment of U.S. society which now has almost full access to such material at cut rate prices: physicians. ${ }^{1 .}$ Experience has failed to show enraged antisocial behavior as a result.

However, let us consider the contrary-to-factconditional. That is, let us assume, if only for the sake of argument, that there is indeed an addictive (or even non addictive) "Godzilla" drug. Should it be prohibited? The answer, at least from the realms of value free economics and the libertarian legal code, is No. From the former perspective, we must still deduce from the sale of this product that both parties gained economic welfare in the ex ante sense. From the latter, it is still unjustified to initiate violence against non initiators, and the imbiber of "Godzilla" will, by stipulation, not begin his crazed rantings, ravings, and waves of murder until at least a few seconds after ingestion. Thus, there is no case for prior restraint on these grounds. It would not be unreasonable, however, for the forces of law and order to carefully monitor such people. Then, as the early stages of this mania begin to take effect (pounding on the chest, drooling, snapping of teeth, whatever) the police can subject him to the fullest penalties of the "real" criminal law as soon as he makes even a slight aggressive move in the direction of a victim. There might be some slight risk of criminal behavior under these circumstances, but it would be far less than in the present situation, where public policy truly unleashes the whirlwind.

A few words of clarification on this matter. At what point would it be all right for officers of the law to intervene? They could do so as soon as there were any indication whatsoever that the person taking this drug were about to go on a rampage. In the extreme case, if we knew with absolute certainty that the Godzilla pill lead necessarily to mayhem (we can never know this, since it is an empirical matter) it would be justified for the police to open fire on the person as soon as ingestion took place. Just as the police may fire at a gunman in order to protect innocent victims long before his bullet has left the pistol chamber, so may they act against "Godzilla" beforc he actually commits violence.

The only difference between the system of legalized drugs advocated in this paper and the present legal regime would be in the motivation of the forces of law and order. They would be executing a murderer, not a drug taker; they would be killing a person not because he took drugs, but because he was about to commit murder, and in order to prevent him from so doing. This might not matter, much, to the user of the Godzilla drug, but this places in stark contrast the difference between prohibition of drugs and prohibition of murder.

We wouldn't hesitate to impose prior constraint to prevent people from swallowing a nuclear bomb. But cannot the Godzilla pill be looked upon akin to a thermonuclear device? No, there is a relevant difference. If a nuclear device blows up, it is beyond the power of the police, or anyone else, to prevent harm to innocent persons. In contrast, if a person swallows the Godzilla pill, the forces of law and order will be able to stop him in his tracks the moment he gives any indication on incipient violence. At most, then, this analysis can support a law calling on purveyors of the Godzilla pill to notify the police of an upcoming sale; it cannot justify prohibition. With the bomb, things are very different; the clear and present danger it constitutes (to say nothing of the fact that it is intrinsically an offensive weapon and should be prohibited on that ground alone) provides reason for its proscription.

Of course, if the Godzilla pill makes the person who takes it all but omnipotent, as well as murderous, then and only then is there a case for prohibition. But in this scenario, Godzilla has left the realm of (addictive?) drugs and entered that of atom bombs.

Consider the following critique of the points made above:

The claim that because there are always a "few seconds" after taking the drug before the Godzilla effect sets in, there is "no case" for prior restraint is ... too strong ... The point need merely be an empirical one. If the probability that someone will have a Godzilla effect shortly after consuming $x$ is nontrivial by not cnormous, then prior restraint is permissible only if the probable losses of permission exceed the probable losses of restraint. The latter are cnormous in the case of drugs, the former comparatively trivial. But the point is that it's an empirical question what they are...

Also, clearly the manufacturer, or the consumer, should ... be required to pay the police (for these guardian services). Certainly the public shouldn't have to subsidize Godzilla-pill pushers by paying the bills for expensive police control of the modest numbers who 
turn animal on us - any more than we should have to subsidize the hospitals catering to junkics.

Although exceedingly well made and forceful, there are several objections which may be registered. First is the issue of measurement: how can one tell, even in principle, whether the probable losses of permission will exceed the probable losses of restraint? Welfare economics speaks out in a loud clear voice about the impermissability of interpersonal comparisons of utility, and this is what such a comparison would involve. Second, is the issue of utilitarianism. Libertarianism is not a theory of maximizing happiness, however construed. Rather, it is a philosophy of rights. "Justice though the heavens fall," is certainly not a statement conducive to the thinking of writers such as Jeremy Bentham. ${ }^{16}$ The issue for the libertarian, then, is not a benefit cost calculation of prior restraint. It is instead an analysis of the rights involved, under the principle that no one may be aggressed against unless he has threatened, or indulged in, uninvited violence against another person. Since, in the few seconds between the taking of the pill and the onset of the Godzilla complex, the imbiber has done neither, it is impermissible to engage in forceable police sanctions against him.

What of the question of the responsibility for the costs of the police guarding us against those who injest the Godzilla pill? Answering this is a difficult and daunting challenge. We may begin the analysis by making a distinction between anarcho-libertarianism (Rothbard, 1973; Hoppe, 1989), and the more widely held view of laissez faire in economics, governed by a government limited to the protection of persons and property.

In the former case, the explanation is straightforward: the people who pay are the clients of the private defence agencies who are worried about the problem. But in the latter case, it is not at all clear that the responsibility for these payments should rest with the manufacturers and consumers of the pill, presumably in the form of an excise tax. Consider some other cases, in order to provide context. Do we confine the outlays made by the police in stopping bank robberies to banks and their clients? Do we restrict the costs of preventing rapes to females? ${ }^{17}$ Do we force children to pay for the police and court expenses of dealing with child abuse? Unless we were willing to inaugurate such policies - and there is little or nothing within the limited government free enterprise philosophy to support this - we cannot consistently demand that the manufacturers and consumers of the Godzilla pill alone be made to finance the related police and court expenditures. ${ }^{1 \times}$

4. If narcotics are legalized, they will gain an imprimatur from the state. Their present legal status should therefore be preserved

The problem with this objection is that legalization does not imply sanction. If it did, extant law with regard to tobacco, alcohol and gambling would suggest that the government favored these goods and services. And yet they are usually subjected to extra taxes, e.g., "sin" taxes. As well, there are many other disreputable activities which are nonetheless legal, at least at present. For example, lying, gossiping, disloyalty to employers, jilting fiancees right at the alter, disrespect to parents, nose picking, cheating at solitaire, not keeping one's lawn trimmed, cutting corners, not taking regular baths, breaking promises to children. If it were true that a failure to legally interdict these activities is reducible to approval of them, then our society, insofar as it does not fine or imprison perpetrators, actually recommends and esteems them. Needless to say, nothing could be further from the truth.

5. The elasticity of demand for narcotics is very high. Small reductions in price will call forth large increases in demand. The gigantic fall in price likely to emerge with legalization would create a stupendously gigantic elevation in use. Were these agents to be legalized, the whole society would become drugged out of its gourd

Although posed in a rather exaggerated form, this objection is a very powerful one indeed. Even ardent advocates of repeal such as Friedman (1989) would change their position on the issue were this elasticity claim to be proven correct. ${ }^{19}$ Fortunatcly for the position taken in this chapter, however, the evidence suggests that the elasticity is likely to be far lower than that depicted in the doomsday scenario. Why?

First of all, the elasticity for drugs in general is very low. This is because such items are usually seen 
by their consumers as necessities, not luxuries. While one might severely reduce demand for the latter in the face of an increased price, or even give it up entirely in the extreme, this does not apply to the former. But if such behavior is characteristic of most drugs, it applies even more so in the case of addictive substances. For at least in the mind of the addict, these are the most difficult of all from which to refrain.

Secondly, the effect of legalization - in markedly reducing profits - will be to greatly decrease the incentive for "pushing." No longer will it pay for addicts to go to school yards, offering free samples, in an attempt to "hook" children into a life of addiction in order to support their own habits. With a free market, where these products will be exceedingly cheap, there will be no temptation to resort to these extraordinary means of salesmanship.

Third, even if quantity increases, potency will fall, as we have seen above. Given this effect, a great amount of total drugs may be less harmful to the population than what is presently consumed, as heroin and cocaine begin to take the place of the more deleterious chemical derivatives, and as marijuana begins to replace those two.

Given this wealth of evidence, we must conclude that it is extremely unlikely that elasticity will prove very high at all. A much more reasonable expectation is that when prices fall due to legalization quantity will not increase much if at all. ${ }^{20}$

There are further reasons too for expecting consumption to actually decline upon legalization. One is the fact that its being made illegal increases its attractions to so many people. If taking heroin were perceived to be merely stupid (the contention of the present author, as it happens) instead of dangerous because illegal, fewer would take it.

We must, however, squarely face the Armageddon scenario. Suppose for argument's sake that evidence to the contrary notwithstanding, what will really happen upon repeal is accurately portrayed by the exaggerated fears of the objection under consideration. Assume, for instance, that $75 \%$ of the population, just to pick a number out of a hat, were to become addicted. We still maintain that there is again nothing in the realm of positive economics, nor of normative libertarian political theory, that can serve as the basis for prohibition. It will still be true that all parties concerned will gain, in their own subjective estimates, from their participation in the drug market. It will still be true that the industry will be a totally voluntary one, with no one forced to take part. Hence, libertarian theory still proscribes interdiction. To be sure, G.N.P./capita will not be as high under such a regime, at least at the outset; but this calculation is a very imperfect estimator of economic welfare, which will be maximized by allowing people to freely choose their consumption patterns. In any case, for those inordinately fond of G.N.P. calculations, there is a consolation. If addiction really is the killer feared by somc, the likelihood is that in the long term G.N.P. will rise at least on a per capita basis, as the death by slow suicide of the addicts raises the average productivity of those who remain.

\section{Advantages}

\section{Decrease in crime}

As legalization takes the vast profits out of the drug business, the incentives toward criminality will tend to disappear pari passu. And this is no accident, since the one stems from the other. According to some estimates (Trebach, 1978), this factor alone accounts for some $50 \%$ of crime in urban America. In addition, with fewer criminals, there will be less overcrowding of prisons; expenditures in this direction will fall. Another saving will be in terms of the monies now expended on crime prevention. Less money will have to be wasted on locksmiths, burglar alarms, gated communities, and fewer ulcers will be generated due to fear and worry about crime. ${ }^{21}$

This point highlights the reason for the difficulty of "fighting the war on drugs." Every time a battle is won in this "war," paradoxically, the enemy is strengthened, not weakened. If one ton of cocaine is seized, the price of this commodity increases; but this subsequent higher value only succeeds in raising the profit incentives attendant upon production. Thus, the more vigorous and successful the activities of the Drug Enforcement Agency, the greater the strength of the illicit drug industry. The way to "win" the war is not by fighting the alligators, but by draining the swamp. As jurists and law enforcement agents in South American and Asian countries have long known, and as their counterparts in the U.S. are 
in the process of ascertaining for themselves, these alligators, the drug gangs, have very sharp teeth indeed. Better to ruin their business by deflating the profit balloon than by acting in a way (prohibition) which only supports them. The present drug war is so far from being won that the authorities cannot even stop their spread in prisons, where civil liberties niceties do not play any nugatory role, and their control is as total as it will ever be in any sector of socicty (Thornton, 1991).

\section{Better health protection}

If even a small part of the money now fruitlessly spent on banning narcotics were instead allocated to the medical problem of curing people of the malady of drug addiction, the average level of health in this country would be vastly improved. This battle is a winnable one, as shown by the great strides made recently in fighting the depredations of alcohol and tobacco. The lowered use of these commodities, especially in the upper classes, which usually set consumption patterns for the rest of society, is a pattern which can and must be emulated for narcotics.

In addition, there is the problem of AIDS. Drug prohibition plays its part in the tragic spread of this dreaded disease because of shared needles. Like so much else, this is a result of the outlawry, not of the narcotics themselves, as can be seen from the fact that insulin addicts (diabetics, that is) need never resort to shared needles. On the contrary, they can avail themselves of the finest medical care that our society can offer. Were we to reverse matters, that is, legalize narcotics but prohibit insulin, there is no doubt that the results would be reversed as well. Crazed and enraged insulin junkies would then commit crimes and spread AIDS through shared needles, while heroin addicts would lead relatively calm and unthreatened lives.

The health of addicts would moreover improve. Lenny Bruce died not from an overdose of heroin, but from impurities in the sample with which he injected himself. This is the modern equivalent of "bathtub gin." If Squibb, Pfizer, Upjohn, Ciba-Giegy, Glaxo, Merck and their ilk were in charge of production instead of a bunch of fly-by-night outfits, there is little doubt that the quality control safeguards would be immeasurably enhanced. Suppose you were about to die and had a child addicted to narcotics. Would you prefer a situation where he had to run around like a half crazed wretch, doing all sorts of unspeakable things in order to raise the requisite funds for his habit, never knowing where his next fix was coming from, nor what would be in it, or one where he could be given an injection in safe comfortable clean hospital surroundings, under the care of a physician?

\section{Civil liberties}

Because drug sales are a victimless crime, the police labor under a disadvantage compared to auto theft, rape, assault, arson, etc. There is no formal complainant. Therefore, if they want to solve the "crime", they must often resort to tactics and techniques which would otherwise prove unnecessary and repugnant. This is why they ride roughshod over civil liberties ${ }^{22}$ in a way that occurs with regard to few if any other crimes. As a result, we have witnessed teen curfews, "zero tolerance" where boats and automobiles have been seized upon the finding of minuscule amounts of marijuana, strip searches, National Guard patrols on our city streets and legal prosecutions for the parents of teen addicts. Political leaders have gone so far as to advocate flogging, cutting off a finger for each drug conviction, the death penalty, and sending the U.S. military to foreign countries to interdict supplies. The civilized world was properly outraged by the shooting down by the Russians of the Korean Airlines commercial jet which strayed from its flight path; what are we to make in this context of the suggestion of Customs Commissioner William von Raab's suggestion (Bandow, 1989) that planes suspected of carrying illegal drugs should be shot out of the sky?

As well, drug legalization - of possession, use, sale, transport, "trafficking," merchandising, advertising, etc..$^{23}$ - is a litmus test for the philosophy of civil liberties. One can hardly be a civil libertarian and favor prohibitionism. Advocacy of legalization, or at least decriminalization, is a necessary albeit not sufficient condition for a civil libertarian. 


\section{Acknowledgements}

The author wishes to thank Steven Luper-Foy and Curtis Brown, both of the philosophy department of Trinity University, for helpful feedback to an earlier version of this paper. He also wishes to express gratitude to an anonymous referee of this journal for criticizing the analysis of Godzilla given here (see pp. 694-695). The usual absolutions apply.

\section{Notes}

* Nothing in this article should be taken as an indication that the author favours the use of the drugs discussed hercin. Actually the very opposite is the case. While he opposes prohibition, he advocates all non-cocrcive methods arguments, counselling, advertising, ctc. - which lead to decreased or zero usage of these pernicious and immoral materials and substances.

1 Actually, relcgalization, since these addictive substances were legal up until 1914, with the passage of the Harrison Narcotics Act.

2 Economics is traditionally divided into normative and positive. The former is valuc-laden, e.g., amalgamated with politics or ethics, and is sometimes called political cconomy. The latter is value free, or scientific, and is, in the minds of most members of the profession, their only legitimate calling. For example, to claim that the minimum wage law will likely lead to heightened unemployment rates for teenaged, handicapped, school drop-outs and other unskilled workers is considered part and parcel of positive economics. To castigate such legislation as improper or inappropriate is deemed normative economics, and is commonly seen as lying outside of the professional competence of the economist. To claim that "there is nothing in the tenets of value free cconomics that would preclude the legalization of drugs" is thus to make a rather strong statement: it is to asscrt that no economist, qua economist, can legitimately argue for prohibition.

There is, however, one exception to this general rulc. In the view of most cconomists, Parcto Optimality is part and parcel of positive, not normative, cconomics. An exchange, or a changed situation is said to be Pareto Optimal if no onc loses from it, compared to his original position, and at least one person gains. Then, there is said to be an unambiguous improvement in economic welfare.

3 We are here discussing third parties whose rights to person and property are not being violated; these people are mercly objecting to the sale of goods and services which affect other people. Later, under the heading of "Godzilla" drugs, we deal with the case of coercion against third partics.
+ Opponents could of course engage in violence. But even this is insufficient to logically imply opposition to the thing itself. Such acts are capable of many alternative interpretations. For example, a person may violently attack an abortion clinic. Does this incluctably prove antagonism to abortion? Not a bit of it. The clinic attacker may mercly be indulging his predilection for engaging in random destruction. Nor will wearing a button, or sporting a placard attesting to the pro-life philosophy, be sufficient to establish true opposition. These are mercly forms of specch. The act of throwing a brick through the window of the abortion clinic, even coupled with pro-choice verbal statements, is no guarantec of true opposition to abortion. Who knows? Perhaps the hoodlum is mercly attempting to drum up business for a glazier, and is hiding behind a facade of women's rights.

"If there is, as in the case where "Doctor Death" assists a person to commit suicide, then there is agreement between the two parties, and their interaction may be analyzed according to the strictures of welfare economics.

"For a definitive defense of libertarianism, see Rothbard, 1973, 1982; Hoppe, 1989.

What of the clash of rights? It is a basic premise of libertarianism that rights, properly construcd, cannot clash. In this vicw, any secming incompatibility between two putative "rights" implies that (at least) one of them has been improperly specified. For example, between the right of frecdom of association and the "right" not to be discriminated against (sec Epstein, 1992); between the right to private property and the "right" to equality, or medical carc or housing (sec Block, 1986); between the right of self ownership and the "right" of the slave owner to his property; only the former in each of these three pairs is legitimate.

* People who are pro-choice on the matter of abortion should appreciate this point. Without taking a side on this debate, note that the pro-choice argument is predicated upon the claim that a woman owns her own body, and therefore she should determine what leaves it, and what remains in it. But if she has the right to rid hersclf of a fetus on this ground, then she also has the right to decide which drugs shall be used by her. But this is not mere compatibility of argument. I go further and claim that it is a logical contradiction to argue that a woman's ownership over her body gives her the right to evict an unwanted fetus, but not to ingest the chemical of her choice into it.

"Consider the following argument "Onc can distinguish between addictions one would choose under conditions of perfect information (good) from addictions one would not (bad). Surely some people who become addicted to drugs would not have chosen to become addicted had they known that this would lead to lost income, harm to health, etc."

This sounds reasonable, but how are we to determine when and if information is "perfect"? Is it ever? Can information ever be perfect? Would we recognize it as such? 
Another variant of this objection concerns the ex post perspective. In this version, good addictions are those we acknowledge are beneficial ex post, bad ones are those we now see as harmful to ourselves. The problem with this is that if we now really saw them as harmful, we would to that extent cease and desist from engaging in them. That we continue to indulge in them is evidence that although we talk negatively about our "bad" habits, when push comes to shove we act as if we think of them as positive. Which indicates our real attitudes: Our specch or our actions? Surely the latter. For further elaboration of this argument, sec Anderson and Block, 1992.

10 Nor are we entitled to deduce that "good" addictions, such as for Bach and Handel, should be made compulsory. This is a normative claim, not a positive scientific onc. If it were truc that classical music enhances future earnings, does it follow that mandating such activity will increase wealth? No. All that we know, by assumption, is that adoption of this musical habit is associated with increased consumption options in future. Even if we could leap from this to the claim that Mozart causes a rise in wealth for those who engage in this practice in a voluntary manner, it would still not follow that listening to him under duress would do the samc. But suppose that money wealth did indeed rise for those forced to listen to his symphonies. This would still not mean that psychic income rose. On the contrary, the presumption is that it fell; that is, that the increase in moncy income was morc than offset by the negative aspects of the coercion. If this were not the casc, the individual in question would always be free to listen to Ein Kleine Nachtmusik on his own.

11 Boaz calls for sale of addictive drugs "only in specially licensed stores - perhaps in liquor stores, perhaps in a new kind of drugstore." As well, he advocates that "It would be illegal to advertise drugs on television and perhaps even in print" (Boaz, 1990, p. 6; also see Fricdman, 1989). These views can perhaps be justified on public relations grounds: drugs are now totally illegal, and such idcas will likcly make legalization appear more acceptable to the public at large. It should be noted, however, that strictly speaking these concessions constitute compromises with the libcrtarian legal code. For from that perspective adults have the right to buy and sell drugs in any institutional arrangement mutually satisfactory to both partics; pcople have the frec speceh right to advertisc anything at all; and any interferences with this market, such as advertising bans or even prescription laws, however preferable to the present regime, arc thus still an infringement on liberty.

12 Socialized medicine lowers premiums, although not necessarily to zero. But any decrease is sufficient to impact the tripwire of moral hazard. It is true that, theoretically, social insurance schemes could involve deductibles, coinsurance, outright payments, etc. to such an extent that pre- miums would be the same as on the market. In this case, there would be no moral hazard. But what would be the point of instituting socialized medicine precisely along the lines that would occur under frec enterprise?

13 There are smoke free airline routes, and no smoking scctions of restaurants, but no counterparts for alcohol.

it According to some experts, PCP has effects not too dissimilar from those described in the text. However, as mentioned therein, this is almost entirely a product of drug prohibition and its related potency effect (see Thomton, 1991).

15 To be sure it is illcgal for physicians to appropriate drugs for personal use. They can steal these substances, but there are the usual disincentives to do so under prohibitionism. However, the difference between doctors and ordinary citizens is that the former arc placed in a position of trust with regard to drugs. The common man, and the man of medicine, will each pay a penalty if caught ingesting illegal substances; but only the latter may have them at a cut rate cost and, given that the latter not the former is entrusted with their carc, the likclihood of capture is much lower. By "cut rate cost" is meant the cost that would obtain were drugs to be legalized. This is the ordinary cost of growing, transporting, refining ctc., the drug. This would be exceedingly modest, since the lion's share of present expense is attributable to the risks of trafficking, and this comes about only under prohibition.

16 However, another strand of libertarianism is the claim that cven though it is rights based, not utilitarian oriented, it will as a matter of fact lead to the maximum happiness of all participants in the social market economy.

17 The incidence of males as victims of rape is very small.

18 This discussion has so far assumed that policing and incarcerating non victimless crime criminals are a large cost. This is certainly so presently, where these industrics are a monopoly of government. However, it is entirely possible that were these activities privatized, the market could accomplish them far more cheaply, or even, radically, at a negative cost. That is, it is within the rcalm of possibility that if criminals were forced to work at hard labor to compensate their victims, and to pay for the costs of capturing, feeding, housing and guarding them, the receipts engendered by them might be larger than these expenses. If so, this would not be the first time in history where people wore held against their will on a profitable basis.

19 Mentioned to this author in private conversation.

20 The British experiment with legalization would appear to constitute counter evidence to this conclusion, for the rate of addiction increased substantially in the aftermath of this initiative. However, there were special circumstances in this case. First, the number of addicts "rose" due to severe under counting of the previous population. Second, afflicted people immigrated to the U.K. from elsewhere in the British 
Dominions, to take advantage of this humane and progressive policy.

2 With decreased drug profits, there will be less suborning and corruption of police forces and jurists. On first assumption this might secm like an advantage, and many prolegalization commentators write as if this were so. Yet the situation is more complicated. For the forces of "law and order" now play a negative role in society. Looked at objectively, their actions unleash a great part of the criminality and misery now afflicting society. Can a weakening of their powers through bribery, corruption and graft be an unmitigated cvil in such a context?

22 Many commentators have labeled compulsory drug testing as yet another violation of civil liberties. It is not included on the list of infringements in the text because the situation is somewhat complex. If government mandates drug testing, this is indecd a violation of the civil rights of the citizenry, since force will be used against persons unwilling to be tested, who have yet not been convicted of any crime. Violence will thus be initiated against a non-initiator. But the situation is very different when a private person "requires" a drug test as the price of his voluntary cooperation with another. I may say to you, "if you want to come visit me in my living room, you shall first have to be tested for drugs." This is not a violation of your civil liberties, since you have no right to cnter my abode without my permission, and I have just cxpressed the price of admission. Similarly, if an employer "requires" a drug test of his employees (or, alternatively, if an employee "requires" a drug test of his employer) this again does not contravene libertarian law, since the employment contract is an agreement between consenting adults, and each has given the terms upon which a contract may be drawn. Similarly with a shopkecper and a customer, the marriage and friendship "market" (I won't buy from or sell to you, or be friends with, or marry you, unless you get thee to a test station), and, indeed, all other consensual relationships.

23 Except for minors.

\section{References}

Anderson, G. and W. Block: 1992, 'The Economics and Ethics of Paternalism: A Reply to George Akcrloff', mimeo.
Bandow, D.: 1989, 'Once Again, A Drug-War Panic', Chicago Tribune March 22.

Block, W: 1976, Defending the Undefendable (Laisscz-Fairc Books, New York).

Block, W.: 1986, The U.S. Bishops and their Critics: An Economic and Ethical Perspective (The Fraser Institute, Vancouver).

Boaz, D. cd.: 1990, The Crisis in Drug Prohibition (The Cato Institute, Washington D.C.).

Epstein, R.: 1992, Forbidden Grounds (Harvard University Press, Cambridgc).

Friedman, M.: 1989, 'An Open Letter to Bill Bennett', Wall Street Journal September 7.

Hamowy, R. ed.: 1987, Dealing With Drugs Consequences of Government Control (The Pacific Institute, San Francisco).

Hoppe, H. H.: 1989, A Theory of Socialism and Capitalism (Kluwer, Boston).

Judson, H. F.: 1974, Heroin Addiction in Britain (Harcourt Brace Jovanovich, New York).

Nozick, R.: 1974, Anardiy, State and Utopia (Basic Books, New York).

Murray, R. N: 1973, For a New Liberty (Macmillan, Ncw York).

Murray, R. N.: 1982, The Ethics of Liberty (Humanities Press, Atlantic Highlands, N.J.).

Murray, R. N.: 1977, 'Toward a Reconstruction of Utility and Welfare Economics' (Center for Libertarian Studies, San Francisco), Occasional Paper \# 3.

Stigler, G. and G. Becker, 'De Gustibus Non Est Disputandum', American Economic Review 67 March, 76-90.

Szasz, T:: 1985, Ceremonial Chemistry: The Ritual Persecution of Drugs, Addicts and Pushers, red cd. (Learning Publications: Holmes Beach FL).

Thornton, M.: 1991, The Economics of Prohibition (The University of Utah Press, Salt Lake City).

Trebach, A.: 1978, 'The Potential Impact of 'Legal' Heroin in America', in A. Trebach (cd.), Drugs, Crime and Politics (Praeger, New York).

$$
\begin{array}{r}
\text { Department of Economics, } \\
\text { College of Holy Cross, } \\
\text { Worcester, MA O1610-2395, } \\
\text { U.S.A. }
\end{array}
$$

